\title{
Escherichia coli pap Genes as well as Adenovirus Type 11 and Type 21, and BK Virus were Involved with Severe Urinary Tract Infection in Infants
}

\author{
Hae-Kyung Park ${ }^{1 *}$, So-Youn Woo ${ }^{1}$, Eun-Ok Lee ${ }^{1}$ Je-Eun Cha ${ }^{1}$, Ko-Eun Lee ${ }^{2}$, \\ Haesook Park ${ }^{2}$ and Seung Joo Lee ${ }^{3}$ \\ ${ }^{I}$ Department of Microbiology, ${ }^{2}$ Department of Preventive Medicine, ${ }^{3}$ Department of Pediatrics, School of Medicine, \\ Ewha Womans University, Seoul, Korea
}

In infants, urinary tract infections (UTIs) are quite common and primarily caused by bacterial pathogens. However, little research has been conducted regarding the relationship between uropathogenic bacteria, virulent genes, and uropathogenic viruses that might induce UTIs in infants. In this study, we evaluated infants with UTIs to determine the influence of bacterial virulent genes and type of viral infections on clinical aspects. First, we detected 44 cases of bacterial UTI from 600 suspected cases in infants and children. We detected $E$. coli urovirulence genes ( $k p s$, usp, pap, ire A, and chf), two enteropathogenic E. coli genes (bfpA, and eae) and four $S$. aureus and $S$. epidermidis genes (mecA, $p v l, b b p$, and $i c a A)$ in urine samples from infant UTI cases. We also simultaneously detected hematuria-related adenovirus type 11,21, and BK virus (BKV) in urine samples by PCR. As a result, E. coli was the most prevalent bacteria and in Dimercaptosuccinic acid (DMSA)-positive UTI cases, the uropathogenic E. coli virulence factor pap was significantly high. We found that BKV detection was significantly higher in DMSA-positive UTI infants (89\%) compared with $50 \%$ of non-UTI (no bacteria detected) cases. These results are indicative of combined multiple bacterial and viral infections and show severe infant pyelonephritis.

Key Words: Uropathogenic E. coli, Adenovirus, BK virus, Infants, urinary tract infection

\section{INTRODUCTION}

Urinary tract infection (UTI) remains a significant cause of serious bacterial infection in young children and infants $(1,2)$. The principal objective of early recognition and treatment of UTI is the prevention of renal parenchymal

Received: August 9, 2011/ Revised: November 18, 2011

Accepted: November 22, 2011

* Corresponding author: Hae-Kyung Park, MD, PhD. Department of Microbiology, School of Medicine, Ewha Womans University 911-1 Mok-6-Dong, Yang-chun-gu, 158-710, Seoul, Korea.

Phone: +82-2650-5737, Fax: +82-2-2653-8891

e-mail: parkhk@ewha.ac.kr

** This study was supported by a research fund from the Youn Kyung Foundation (2009). June Seng Lee is acknowledged for his skilled cooperation with PCR experiments. damage and subsequent renal scarring (3). Urine cultures remain the gold standard for identifying the causative agents of UTI during diagnosis and treatment (4). Escherichia coli (E. coli), Klebsiella sp., Proteus sp., Pseudomonas sp., and Enterococci account for more than $95 \%$ of urinary isolates. However, age-specific and gender-specific trends have been noted and must be considered in the pathogenesis of UTI $(5,6)$. E. coli is the most frequently isolated pathogen in acute uncomplicated UTIs, and the pathogenic potential of $E$. coli strains is believed to depend on the presence of virulence factors. Urovirulence factors of $E$. coli analyzed via multiplex PCR are useful markers for the detection of uropathogenic E. coli (UPEC) (7).

UTIs are common and are usually induced by bacterial 
pathogens in infants. However, viruses have been identified as a relatively uncommon cause of UTIs in immunocompetent hosts, and only a few studies have been conducted in infants. Some young recipients of stem cell transplants excrete polyoma BK virus (BKV) or adenovirus asymptomatically in their urine (8). However, adenoviral UTIs in immunocompetent infant is a subject that is rarely studied. BKV has been identified as the principal relevant pathogen in hemorrhagic cystitis occurring after bone marrow transplantation and is frequently detected in the urine of these patients $(9,10)$.

Here, we studied bacteria and viruses in multiple combined infections with respect to their influence on UTIs progression in infants. We addressed the simultaneous detection of several virulent genes, including five $E$. coli urovirulence genes (kps, usp, pap, ireA, and cnf), two enteropathogenic E. coli (EPEC) genes ( $b f p A$, and eae) and four $S$. aureus and $S$. epidermidis genes (mecA, pvl, bbp, and $i c a A$ ) in urine samples from infant UTI cases. We also simultaneously detected hematuria-related adenovirus type 11,21 , and BKV in urine samples by PCR.

\section{MATERIALS AND METHODS}

\section{Clinical specimens}

The infants and young children evaluated in this study were all admitted to the emergency room of the Ewha Woman's University, School of Medicine at the Mok-dong Hospital in Seoul, Korea between February 1, 2007 and October 30, 2009. Urine samples from 600 febrile infants and young children were collected and these urine samples were divided into two tubes: one for diagnostic analysis of UTI in the hospital, and we received the other tubes containing $1 \mathrm{ml}$ for PCR study. Informed consent was obtained from the children's parents before the commencement of the study. Collected urine samples $(10 \mu \mathrm{l})$ from 600 cases of suspected UTIs in infants and young children were inoculated on brain-heart infusion (BHI) agar plates as well as MacConkey agar plates, and then incubated overnight at $37^{\circ} \mathrm{C}$. Bacterial colonies were counted and colony identification was done using API20E kits (bioMetrieux, Inc.,
Hazelwood, MO, USA) for enteric bacteria. Gram staining and coagulase tests were followed by the identification of colonies of Staphylococci.

\section{Bacterial DNA preparation for PCR}

We inoculated isolated and identified organisms in MacConkey agar plate at $37^{\circ} \mathrm{C}$. DNA was extracted from bacteria by resuspending one bacterial colony in $80 \mu \mathrm{l}$ of sterile water, incubating for $40 \mathrm{~min}$ at $85^{\circ} \mathrm{C}$ for heat inactivation, and subsequently putting on ice. The mixtures were centrifuged for $20 \mathrm{~min}$ at $16,000 \times g$ and the supernatant was used for the DNA template for PCR.

\section{Multiplex PCR assay}

The bacterial DNA templates were subjected to multiplex PCR with specific primers (Table 1) for the detection of the following virulence markers: kps (capsule gene of UPEC), usp (uropathogenic-specific gene), ireA (iron-regulated siderophore receptor gene), pap (pyelonephritis-associated pili), $c n f$ (cytotoxic necrotizing factor), $b f p A$ (structural gene for bundle-forming pilus of typical EPEC), eae (structural gene for intimin of EPEC and enterohemorrhagic E. coli [EHEC]), mecA (methicillin-resistance gene), pvl (PantonValentine leukocidin, a pore-forming toxin), $b b p$, and icaA (adherence factor of $S$. aureus). The PCR mixture consisted of $10 \times$ PCR buffer, 1.5 or $2 \mathrm{mM} \mathrm{MgCl}, 200 \mu \mathrm{M} \mathrm{dNTP \text {, }}$ 25 40 pmole of each primer, and 2 units Taq polymerase in a final volume of $50 \mu \mathrm{l}$. A thermocycler (Takara Bio Inc., Otsu Shiga, Japan) was used for 40 cycles of $95^{\circ} \mathrm{C}$ for 1 $\min , 60^{\circ} \mathrm{C}$ for $1 \mathrm{~min}$, and $72^{\circ} \mathrm{C}$ for $1 \mathrm{~min}$, followed by a final 8-min extension step at $72^{\circ} \mathrm{C}$. The PCR products were resolved by electrophoresis on a $3.3 \%$ NuSieve agar gel (Figs. 1 and 2).

\section{Detection of viruses in urine samples}

In order to culture and isolate pre-existing viruses in urine samples, HEp-2 cells were added to samples and 4 days later, the cells were harvested with culture medium. We performed the indirect immunofluorescence staining with spot slide method to detect adenoviruses 1, 2, 5, and 6, and BKV with monoclonal antibodies (data not shown). Viral 
Table 1. PCR primers for virulent genes used in this study

\begin{tabular}{|c|c|c|c|c|}
\hline Bacteria & Gene & Primer sequence & Product size (bp) & Reference \\
\hline \multirow{10}{*}{$\begin{array}{l}\text { Uropathogenic } \\
\text { E. coli }\end{array}$} & \multirow{2}{*}{$k p s$} & 5'-CCA TCG ATA CGA TCA TTG CAC-3' & \multirow{2}{*}{400} & \multirow{2}{*}{ (11) } \\
\hline & & 5'-ATT GCAAGG TAG TTC AGACTC-3' & & \\
\hline & \multirow{2}{*}{ pap } & 5'-GAC GGC TGT ACT GCA GGG TGT GGC G-3' & \multirow{2}{*}{328} & \multirow{2}{*}{$(12)$} \\
\hline & & 5'-ATA TCC TTT CTG CAG GGA TGC AAT-3' & & \\
\hline & \multirow{2}{*}{ usp } & 5'-ACA TTC ACG GCA AGC CTC AG-3' & \multirow{2}{*}{440} & \multirow{2}{*}{ (13) } \\
\hline & & 5'-AGC GAG TTC CTG GTG AAA GC-3' & & \\
\hline & \multirow{2}{*}{ ireA } & 5'-ATT TCC CCG CAT CCA GG-3' & \multirow{2}{*}{315} & \multirow{2}{*}{ (14) } \\
\hline & & 5'-CCC TGT ATG GTT CTG ATG C-3' & & \\
\hline & \multirow{2}{*}{ chf } & 5'-AAG ATG GAG TTT CCT ATG CAG GAG-3' & \multirow{2}{*}{498} & \multirow{2}{*}{$(12)$} \\
\hline & & 5'-CAT TCA GAG TCC TGC CCT CAT TAT-3' & & \\
\hline \multirow{4}{*}{$\begin{array}{l}\text { Enteropathogenic } \\
\text { E. coli }\end{array}$} & \multirow[b]{2}{*}{ eae } & 5'-GGC CAG CGT TTT TTC CT CCT G-3' & \multirow{2}{*}{377} & \multirow{2}{*}{$(15)$} \\
\hline & & 5'-TCG TCA CCAAAG GAA TCG GAG-3' & & \\
\hline & \multirow{2}{*}{$b f p A$} & 5'-AAT GGT GCT TGC GCT TGC TGC-3' & \multirow{2}{*}{326} & \multirow{2}{*}{ (16) } \\
\hline & & 5'-GCC GCT TTA TCC AAC CTG GTA-3' & & \\
\hline \multirow{8}{*}{$\begin{array}{l}\text { S. aureus and } \\
\text { S. epidermidis }\end{array}$} & \multirow{2}{*}{ mecA } & 5'-GTA GAA ATG ACT GAA CGT CCG ATA-3' & \multirow{2}{*}{310} & \multirow{2}{*}{$(17)$} \\
\hline & & 5'-CCAATT CCA CAT TGT TTC GGT CTA-3' & & \\
\hline & \multirow{2}{*}{$p v l$} & 5'-ATC ATT AGG TAAAAT GTC TGG ACA TGA TCC A-3' & \multirow{2}{*}{433} & \multirow{2}{*}{ (17) } \\
\hline & & 5'-GCA TCA AST GTA TTG GAT AGC AAAAGC-3' & & \\
\hline & \multirow{2}{*}{$b b p$} & 5'-AAC TAC ATC TAG TAC TCA ACA ACA G-3' & \multirow{2}{*}{575} & \multirow{2}{*}{$(18)$} \\
\hline & & 5'-ATG TGC TTG AAT AAC ACC ATC ATC T-3' & & \\
\hline & \multirow{2}{*}{$i c a A$} & 5'-ACA GTC GCT ACG AAA AGAAA-3' & \multirow{2}{*}{103} & $(1)$ \\
\hline & & 5'-GGA AAT GCC ATA ATG ACA AC-3' & & (19) \\
\hline
\end{tabular}

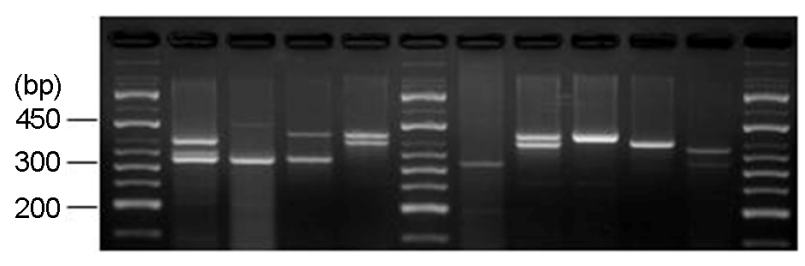

Figure 1. NuSieve agar gel showing detection of five urovirulent genes ( $k p s, u s p$, pap, cnf, and ire A) and enteropathogenic genes of E. coli (eae and $b f p A$ ) in infant urine by multiplex PCR. Lane 1, DNA marker (50-bp ladder); Lane 2, kps (400 bp) and pap (328 bp) both positive; Lane 3, cnf (498 bp) and pap (328 bp) both positive; Lane 4, usp (440 bp) and pap (328 bp) both positive; Lane 5, usp (440 bp) and kps (400 bp) both positive; Lane 6, DNA marker (50-bp ladder); Lane 7, pap (328 bp) positive; Lane 8, usp (440 bp) and kps (400 bp) both positive; Lane 9, usp (440 bp) positive; Lane 10, kps (400 bp) positive; Lane 11, eae (377 bp) and bfpA (326 bp) both positive; Lane 12, DNA marker (50-bp ladder).
DNA extracted from HEp-2 cell culture or urine samples were purified using the QiaAmp DNA mini kit (Qiagen $\mathrm{GmbH}$, Hilden, Germany) and used in monoplex PCR. The primer sets used are listed in Table 2 . The reaction mixture contained $2 \mathrm{mM} \mathrm{MgCl}_{2}$ and 25 30 pmoles of each primer; annealing temperatures were 52,61 , or $72^{\circ} \mathrm{C}$ for $1 \mathrm{~min}$. The PCR products were loaded on 3.3 3.57\% NuSieve agar gels and visualized by Sony photography (Figs. 3, 4, and 5).

\section{Statistical analysis}

Analysis of variance (ANOVA) for unbalanced data was conducted to analyze the results for significant differences (at $p<0.05$ ), using SAS 9.1 software. 
Table 2. PCR primer sequences used in this study for adenovirus type 11, 21, and BKV

\begin{tabular}{clcc}
\hline \hline Virus & \multicolumn{1}{c}{ Primer Sequence } & PCR product size (bp) & Reference \\
\hline \multirow{2}{*}{ AD11 } & 5'-GAC ATG ACT TTC GAG GTC GAT CCC ATG GA-3' & 139 & $(20)$ \\
& 5'-CCG GCT GAG AAG GGT GTG CGC AGG TA-3' & & $(21)$ \\
AD21 & 5'-GAA ATT ACA GAC GGC GAA GCC-3' & 237 & $(20)$ \\
& 5'-AAC CTG CTG GTT TTG CGG TTG-3' & & 175 \\
BK virus & 5'-AGT CTT TAG GGT CTT CTA CC-3' & & $($ 5'-GGT GCC AAC CTA TGG AAC AG-3' \\
\hline
\end{tabular}

AD11, Adenovirus type 11; AD21, Adenovirus type 21.

\section{RESULTS}

\section{UTI cases were selected from urine samples and bacteria were identified}

We isolated bacteria from urine samples collected from suspected UTI cases in infants and young children. In terms of bacterial count, $10^{4} \sim 10^{5}$ bacteria colony forming unit $(\mathrm{CFU}) / \mathrm{ml}$ of urine were defined as UTI in infants and young children with fever. Among the 44 cases out of 600 cases $(44 / 600,7.3 \%)$ in which bacterial colony counts of $10^{4} \sim 10^{5} \mathrm{CFU} / \mathrm{ml}$, bacteria were identified: E. coli $(33 / 44$, $75.0 \%$ ) was the most frequent bacteria and P. mirabilis (7/44, 15.9\%), S. aureus (3/44, 6.8\%) and S. epidermidis $(1 / 44,2.2 \%)$ were the next most frequent, in that order. Morexella catarrhalis, Pseudomonas aeruginosa, Candida albicans, Klebsiella species, and other fungi were excluded if the colony count numbers were $10^{2} \mathrm{CFU} / \mathrm{ml}$ or less.

\section{Detection of urovirulent and enteropathogenic genes} of $E$. coli in urine samples

In order to evaluate the relation between the expression of virulent genes and the severity of UTI in infants and children, we detected the urovirulent genes ( $k p s$, usp, pap, $c n f$, and ire A) and enteropathogenic genes (bfp, and eae) of E. coli in 33 cases of $10^{4} \sim 10^{5} \mathrm{CFU} / \mathrm{ml}$ UTI (Fig. 1 and Table 3). Furthermore, for the detection or evaluation of kidney damage, we reviewed the medical records of dimercaptosuccinic acid (DMSA) scan reports from UTI patients and the results were positive in 11 cases of $10^{4} \sim 10^{5} \mathrm{CFU} /$ $\mathrm{ml}$ of $E$. coli UTI. Therefore, we divided the 33 samples of
Table 3. The relationship between DMSA-positive pyelonephritis and the detection rate of $E$. coli virulent genes

\begin{tabular}{lccc}
\hline \hline Virulence genes & $\begin{array}{r}\text { DMSA (-) UTI } \\
\text { N (\%) }\end{array}$ & $\begin{array}{c}\text { DMSA (+) UTI } \\
\text { N (\%) }\end{array}$ & $p$ \\
\hline Urovirulent E. coli genes & & \\
kap & $16(73 \%)$ & $10(91 \%)$ & 0.38 \\
usp & $12(55 \%)$ & $9(82 \%)$ & 0.25 \\
pap & $9(41 \%)$ & $10(91 \%)$ & 0.01 \\
cnf & $9(41 \%)$ & $7(64 \%)$ & 0.28 \\
ireA & $6(27 \%)$ & $5(45 \%)$ & 0.44 \\
Enteropathogenic E.coli genes & & \\
bfpA & $3(14 \%)$ & $3(27 \%)$ & 0.38 \\
eae & $4(18 \%)$ & $0(0 \%)$ & 0.28 \\
\hline Total case & 22 & 11 & \\
\hline
\end{tabular}

DMSA, Dimercaptosuccinic acid.

E. coli positive cases into 22 cases of DMSA-negative and 11 cases of DMSA-positive. The pap gene was detected in DMSA-positive E. coli UTI at a frequency of $91 \%(10 / 11)$ and in DMSA-negative E. coli UTI at a frequency of $41 \%$ (9/22). According to these results, the pap gene exerted significantly pathogenic influence on pyelonephritis ( $p=$ 0.01). The EPEC virulence eae and $b f p A$ genes, however, did not show a significant difference between the DMSAnegative and DMSA-positive groups of $E$. coli UTIs in infants (Table 3).

Detection of virulent genes of $S$. aureus and $S$. epidermidis in urine samples by multiplex PCR

In UTI infection, Staphylococcus originated from skin can cause UTI and often it can be involved with antibiotic- 

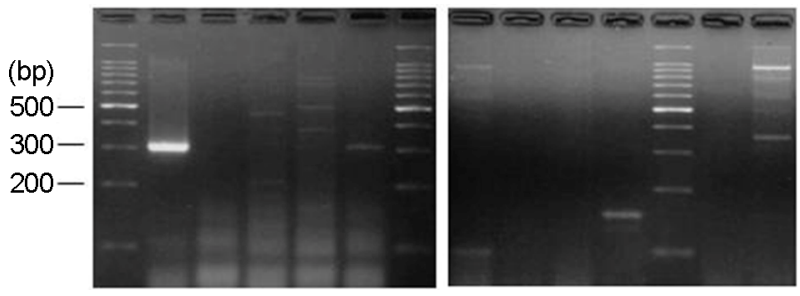

Figure 2. NuSieve agar gel showing results of $S$. aureus and $S$. epidermidis virulence genes ( $m e c A, p v l, b b p$, and $i c a A$ ) detected in infant urine by multiplex PCR. Lane 1, DNA marker (100-bp ladder); Lane 2, mecA (310 bp) positive; Lane 4, pvl (433 bp) positive; Lane 6, mecA (310 bp) positive; Lane 7, DNA marker (100-bp ladder); Lane 8, bbp (575 bp) and icaA (103 bp) both positive; Lane 12, DNA marker (100-bp ladder).

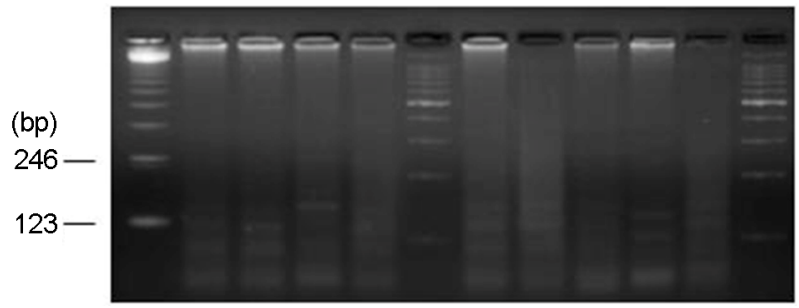

Figure 3. NuSieve agar gel showing results of adenovirus type 11 (139 bp) detected in infant urine by monoplex PCR. Lane 1, DNA marker (123-bp ladder); Lane 4, AD11 positive; Lane 6, DNA marker (100-bp ladder); Lane 8, AD11 positive; Lane 11, AD11; Lane 12, DNA marker (100-bp ladder).

resistance genes or adherence factors for further progression of the infection. Therefore, next we assayed the mecA, pvl, $b b p$, and icaA genes by multiplex PCR targeted to $S$. aureus ( 3 cases of $10^{5} \mathrm{CFU} / \mathrm{ml}$ and 15 cases of $10^{2} \sim 10^{3} \mathrm{CFU} / \mathrm{ml}$ ) and $S$. epidermidis ( 1 case of $10^{5} \mathrm{CFU} / \mathrm{ml}$ and 14 cases of $\left.10^{2} \sim 10^{3} \mathrm{CFU} / \mathrm{ml}\right)$. The mecA gene for $S$. aureus was detected in 12/18 (67\%) cases, and pvl genes were detected in $10 / 18$ cases $(56 \%)$. The icaA gene was detected in the same urine $(8 / 18,44 \%)$, and the $b b p$ gene $(6 / 18,33 \%)$ was detected with high positivity by multiplex PCR. In the $10^{2} \sim 10^{3} \mathrm{CFU} / \mathrm{ml}$ S. aureus UTIs, 15 cases contained highpositivity virulent genes (mecA, pvl, bbp , and icaA), the detection of which may be associated with a pathogenic role of UTI in infants. The detection rate of the mecA, pvl, and icaA genes in $S$. epidermidis was highly positive, but detection of $b b p(1 / 15,7 \%)$ produced relatively low positivity (Fig. 2).

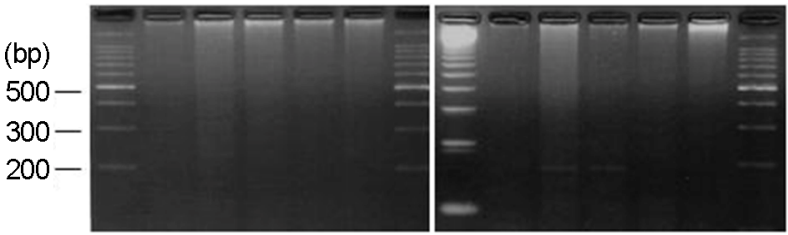

Figure 4. NuSieve agar gel showing results of adenovirus type 21 (237 bp) detected in infant urine by monoplex PCR. Lane 1, DNA marker (100-bp ladder); Lane 3, AD21 positive; Lane 7, DNA marker (100-bp ladder); Lane 8, DNA marker (123-bp ladder); Lane 10, AD21 positive; Lane $11, \mathrm{AD} 21$ positive; Lane 14 , DNA marker (100-bp ladder).

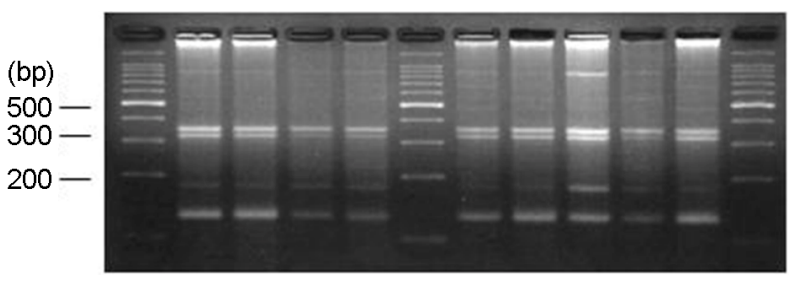

Figure 5. NuSieve agar gel showing results of BKV (179 bp) detected in infant urine by monoplex PCR. Lane 1, DNA marker (100-bp ladder); Lane 2, BKV positive; Lane 3, BKV positive; Lane 4, BKV positive; Lane 5, BKV positive; Lane 6, DNA marker (100-bp ladder); Lane 7, BKV positive; Lane 8, BKV positive; Lane 9, BKV positive; Lane 11, BKV positive; Lane 12, DNA marker (100-bp ladder)

Selection of urine samples from young children with and without UTI for the isolation of adenovirus type 11, type 21, and BKV

In this study, we selected gross hematuria (7 cases), turbid or sedimented urine (14 cases), and gross clear urine (8 cases), from $10^{4} \sim 10^{5} \mathrm{CFU} / \mathrm{ml}$ bacteria-counted urine samples (male $:$ female $=19: 10$, mean age $=5.1$ months). We also selected gross hematuria (6 cases), turbid or sedimented urine (15 cases), and gross clear urine (11 cases) from 32 cases in which bacteria were not counted (male: female $=13: 19$, mean age $=6.0$ months), which were selected as the control group for uropathogenic adenovirus type 11, type 21 , and BKV detection by monoplex PCR (Fig. 3, 4, and 5). In 18 cases of DMSA-positive urine with E. coli UTI, adenovirus type 11 (15/18, 83\%), adenovirus type $21(10 / 18,56 \%)$, and BKV (16/18 cases, 89\%) were detected at the highest rate (Table 4). The detection rate of BKV was highest at $89 \%$ in the cases of DMSA-positive 
Table 4. The relationship between DMSA-positive pyelonephritis and the detection rate of AD 11, A21 or BKV

\begin{tabular}{cccccc}
\hline \hline \multirow{2}{*}{ Virus } & $\begin{array}{c}\text { Bacteria Culture (-) } \\
\text { N (\%) }\end{array}$ & $\begin{array}{c}\text { DMSA (-) UTI } \\
\text { N (\%) }\end{array}$ & $\begin{array}{c}\text { DMSA (+) UTI Pyelonephritis } \\
\text { N (\%) }\end{array}$ & $\begin{array}{c}\text { Total } \\
\text { N (\%) }\end{array}$ & $p$ \\
\hline A11 & $20(63 \%)$ & $6(55 \%)$ & $15(83 \%)$ & $41(67 \%)$ & 0.17 \\
A21 & $11(34 \%)$ & $6(55 \%)$ & $10(56 \%)$ & $27(44 \%)$ & 0.13 \\
BKV & $16(50 \%)$ & $7(64 \%)$ & $16(89 \%)$ & $39(64 \%)$ & 0.01 \\
\hline Total case & 32 & 11 & 18 & 61 \\
\hline
\end{tabular}

AD11, Adenovirus type 11; AD21, Adenovirus type 21.

Table 5. The combined result of DMSA scan, the detection rate of virus, occult blood in the urine and E. coli virulent genes

\begin{tabular}{|c|c|c|c|c|c|c|c|c|c|}
\hline \multirow{2}{*}{$\begin{array}{c}\text { Bacteria culture } \\
-\end{array}$} & \multirow{2}{*}{$\begin{array}{c}\text { DMSA } \\
-\end{array}$} & \multicolumn{2}{|c|}{$\begin{array}{c}3 \text { viruses detected } \\
\text { N, \% }\end{array}$} & \multicolumn{2}{|c|}{$\begin{array}{l}\text { Occult blood } \\
\text { N/field }\end{array}$} & \multicolumn{2}{|c|}{$\begin{array}{c}\geq 4 \text { of } 5 \text { UPECs } \\
\text { detected } \\
\mathrm{N}, \%\end{array}$} & \multicolumn{2}{|c|}{$\begin{array}{c}\geq 1 \text { of } 2 \text { EPECs } \\
\text { detected } \\
\mathrm{N}, \%\end{array}$} \\
\hline & & $3 / 32$ & $9 \%$ & 1.42 & \pm 1.52 & & & & \\
\hline+ & - & $3 / 11$ & $28 \%$ & . & & $3 / 22$ & $14 \%$ & $5 / 22$ & $23 \%$ \\
\hline+ & + & $6 / 12$ & $50 \%$ & 2.83 & \pm 1.11 & $5 / 7$ & $71 \%$ & $1 / 7$ & $14 \%$ \\
\hline+ & ++ & $2 / 6$ & $33 \%$ & 3.00 & \pm 0.89 & $3 / 4$ & $75 \%$ & $2 / 4$ & $50 \%$ \\
\hline$p$ & & \multicolumn{2}{|c|}{0.02} & \multicolumn{2}{|c|}{$<0.01$} & \multicolumn{2}{|c|}{0.01} & \multicolumn{2}{|c|}{0.43} \\
\hline
\end{tabular}

Table 6. The relationship between AD11, AD21, and BKV detection and occult blood in the urine

\begin{tabular}{|c|c|c|c|c|c|c|c|c|c|}
\hline \multirow{3}{*}{$\begin{array}{l}\text { Virus } \\
\text { A11 }\end{array}$} & \multicolumn{7}{|c|}{$\begin{array}{l}\text { Occult blood } \\
\text { N, \% }\end{array}$} & \multicolumn{2}{|c|}{$\begin{array}{l}\text { Average occult blood No. } \\
\text { (N/field) }\end{array}$} \\
\hline & \multicolumn{2}{|c|}{0} & \multicolumn{2}{|c|}{1} & \multicolumn{2}{|c|}{$\geq 2$} & \multirow{2}{*}{$\frac{p}{0.05}$} & \multirow{2}{*}{$\begin{array}{c}\text { Virus }(+) /(-) \\
2.26 / 1.13\end{array}$} & \multirow{2}{*}{$\begin{array}{c}p \\
0.02\end{array}$} \\
\hline & $7 / 35$ & $20 \%$ & $5 / 35$ & $14 \%$ & $23 / 35$ & $66 \%$ & & & \\
\hline A 21 & $2 / 21$ & $10 \%$ & $4 / 21$ & $19 \%$ & $15 / 21$ & $71 \%$ & 0.03 & $2.57 / 1.45$ & 0.01 \\
\hline $\mathrm{BK}$ & $6 / 32$ & $19 \%$ & $5 / 32$ & $16 \%$ & $21 / 32$ & $66 \%$ & 0.06 & $2.19 / 1.44$ & 0.10 \\
\hline
\end{tabular}

UTI. In the 11 cases of DMSA-negative E. coli UTI, adenovirus type $11(6 / 11,55 \%)$, adenovirus type $21(6 / 11$, $55 \%)$, and BKV (7/11 cases, 64\%) were detected with high positivity ( $p=0.01$, Table 4$)$. In the infants with DMSApositive $E$. coli UTIs, the detection frequencies of $E$. coli urovirulent genes and uropathogenic viruses were increased. As the DMSA intensity (negative to strong positive) increased, the frequency of $E$. coli urovirulent gene detection also increased ( $p=0.01$, Table 5).

\section{Influence of virus in occult blood from infant urine with UTI}

The detection of three uropathogenic viruses in occult blood urine from infants with UTI by monoplex PCR showed increasing prevalence and statistical significance (Table 6). As the occult blood number increased, implying severe hematuria, virus detection frequency also increased, and this was particularly the case for adenoviruses types 11 and 21 (Table 6). The average frequency with which three viruses were detected was directly related to the amount of occult blood in the urine of the infants with UTI $(p=0.02$, Table 7). This implies that infants with severe hematuria showed a higher probability of infection with multiple viruses (Table 7). Clinically, 32 urine samples in which bacteria were not counted showed primary viral mild systemic symptoms, but in the three cases in which all three 
Table 7. Positive relationship between virus detection number and amount of occult blood in infant urine

\begin{tabular}{crcccc}
\hline \hline Occult blood & No. & Average virus detection No. & $p$ & $\begin{array}{c}\text { Proportion in which all 3 } \\
\text { viruses were detected (\%) }\end{array}$ & $p$ \\
\hline 0 & 13 & 1.15 & & $0 \%$ \\
1 & 9 & 1.16 & $<0.01$ & $11 \%$ & 0.02 \\
$\geq 2$ & 28 & 2.11 & $36 \%$ & \\
\hline
\end{tabular}

viruses were detected (1-, 3-, and 12-month-old infants), hemorrhagic cystitis was detected (data not shown). These results imply that these infant UTIs were due to combined bacterial and viral multiple infection.

\section{DISCUSSION}

In this study, we detected 11 virulence genes of three bacteria (E. coli, S. aureus, and S. epidermidis) from 600 cases of suspected UTI urine samples in infants. Among them, E. coli was the most prevalent bacteria and in DMSApositive UTI cases, the uropathogenic E. coli virulence factor pap was significantly high (Table 3 ). We also analyzed the relationship between severe UTI, reflected by DMSApositive, and three uropathogenic viruses (adenovirus type 11,21 , and BKV) in the urine samples by monoplex PCR (Table 4). We found that BKV detection was significantly higher in DMSA-positive UTI infants (89\%) compared with $50 \%$ of non-UTI (no bacteria detected) cases (Table 4). In addition, the detection rate of adenovirus type 11 and type 21 was significantly associated with an increase of occult blood (Table 6). In addition, the intensity of occult blood detection increased with the combination of three uropathogenic viruses (Table 7).

Seven virulence genes ( $k p s$, usp, ire A, pap, cnf, bfp A, and eae) have been assayed for the confirmation of the pathogenic roles of $E$. coli UTI, which have not been reported previously in infants. Uropathogenic specific protein ( $u s p$ ) has been shown to significantly enhance the infectivity of $E$. coli in a mouse UTI model (13). We described the E. coli urovirulence genes, kps (capsule gene) (11) and pap (piliassociated pyelonephritis) in urine obtained from UTI cases in young children. Arisoy et al. suggested the important role of pilus-associated pyelonephritis ( $p a p$ ) in the causation of UTI (12), as we have shown in this study (Table 3). In this study, the pap gene was detected in 10 infants with DMSA-positive urine $(10 / 11,91 \%)$ clinically diagnosed with pyelonephritis, reflecting the profound relationship of the pap gene to pyelonephritis in infants (Table 3). Cytotoxic necrotizing factor $(c n f)$ performs an important function in the pathogenicity of $E$. coli strains by overcoming host defense mechanisms and causing disease (12). Iron-responsive element (ire A) encodes a new virulence factor, which is probably involved in iron acquisition. Iron acquisition is a critical requirement for any microorganism, and particularly for a pathogen that must grow within a host that actively attempts to limit iron availability (14). However, in this study neither $c n f$ nor ireA contribute to DMSA-positive severe form of UTI in infants.

EPEC is transmitted via the fecal-oral route and is the principal cause of infantile bloody diarrhea in developing countries. The primary mechanism underlying EPEC pathogenesis is a lesion, referred to as attaching and effacing $(\mathrm{A} / \mathrm{E})$, which is characterized by the intimate adherence of the bacteria to the intestinal epithelium (22). The E. coli attachment and effacement (eae) gene, the pathogenicity island, the locus of enterocyte effacement, the bundle forming pili $(b f p A)$ gene in the plasmid, and the EPEC adherence factor (EAF) all required assessment for this group of bacteria to be classified into typical and atypical strains (23). In this study, we tested EPEC eae (structural gene for the intimin of EPEC and EHEC), $b f p A$ (structural gene for the bundle forming pili [BFP] of typical EPEC) as contributing factors to UTI in infants comparing with roles of urovirulent $E$ coli genes. As expected, there was no significance between UTI and EPEC genes in this study (Table 3).

Methicillin-resistant $S$. aureus remains rare as a cause of 
bacteriuria, but its incidence has increased over the past decade (24). S. aureus and S. epidermidis contain a methicillin-resistant (mecA) gene and a Panton-Valentain leukocidin $(p v l)$ gene that have been previously detected in cases of infant UTI, but this has not been reported except in one previous study (17). In the present study, in 18 cases of $S$. aureus ( 3 cases of $10^{5} \mathrm{CFU} / \mathrm{ml}$ UTI and 15 cases of $10^{2} \sim 10^{3} \mathrm{CFU} / \mathrm{ml}$ were included), the mecA $(12 / 18,67 \%)$, $p v l(10 / 18,56 \%)$, icaA (8/18, 44\%), and $b b p(6 / 18,33 \%)$ genes were detected with high positivity via multiplex PCR.

As shown in this study, BKV detection correlated to DMSA-positive UTI and virus detection related to occult blood in the urine (Table 4 and 6). Viral causative etiologies may contribute directly to the development of hemorrhagic cystitis in pediatric and adult populations. It has been reported that damage to the bladder transitional epithelium and blood vessels by toxins, drugs, radiation, or viruses/ bacteria may induce hemorrhagic cystitis (25).

Adenovirus has been identified in 51 different known serotypes. Hemorrhagic cystitis is most commonly caused by type 11, and the presence of adenovirus in urine is observed almost exclusively in cases of hemorrhagic cystitis (26). Adenovirus type 11 was recently isolated from tissue cultured from a 15-year-old male patient with acute lymphoblastic leukemia in complete remission who had received an allogenic bone marrow transplant 22 days prior (27). Hemorrhagic cystitis is a common late onset complication of allogenic stem cell transplantation and is principally attributable to type 11 adenoviral infections in young children (20) or polyoma virus (BKV) (28). Although hemorrhagic cystitis has been recognized as a complication of chemotherapy due to viral UTI (29), adenoviral UTI have been previously reported in an immunologically competent 12 year-old female patient who developed acute renal failure as the result of acute necrotizing tubule interstitial nephritis induced by a systemic adenoviral infection (30). In immunocompetent children with adenoviral infections, the incidence of hematuria was $18.6 \%$, with $2.4 \%$ of these children having macroscopic hematuria and upper tract involvement (31). Adenoviral-associated microscopic hematuria is generally relatively benign, but when macroscopic hematuria or associated proteinuria are present it may induce or reveal an underlying glomerulonephritis (31).

BKV is a double-stranded DNA polyoma virus, which was isolated initially in 1971 from a urine sample obtained from a renal transplant recipient, after whom the virus was named (32). Human polyoma virus infections occur most frequently in immunosuppressed children. In the previously reported case, self-limited hemorrhagic cystitis due to polyomavirus infection in a 5-year-old boy was confirmed by real-time PCR (33). In immune competent children, BK virus infection can result in dysuria and hematuria. BK urinary tract infection can be confirmed by urine cytology and immunochemical staining, PCR, and electron microscopy of viral cultures (33). BKV infection should be suspected in a patient with immune deficiencies who presents with hemorrhagic cystitis, microscopic hematuria, hydronephrosis, and an increase in creatinine (33).

In this study, adenovirus type 11 (20/32 cases, 63\%), BKV (16/32 cases, 50\%), and adenovirus type 21 (11/32 cases, 34\%) were detected in 32 infant urine samples, from which no bacteria were detected (Table 4). However, our adenovirus detection rates were higher than those reported previously by Allen et al. (31). Clinically, these 32 infants in which bacteria were not detected, but uropathogenic adenoviruses type 11 and 21 and BKV were detected, suffered from mild cystitis symptoms. However, of the 29 urine samples in which we detected $10^{4} \sim 10^{5} \mathrm{CFU} / \mathrm{ml}$ of UTI bacteria, uropathogenic adenovirus types 11 and 21 and BKV were simultaneously detected in five cases (mean age 3.6 months); in all five of these cases, the infants suffered from severe pyelonephritis (data not shown). These cases apparently involved multiple infections with a combination of bacteria and viruses in the UTI infants. All infants had severe hematuria and were regarded as likely cases of multiple virus infection.

Proteus mirabilis is a common cause of urinary tract infection in patients, and may induce cystitis and serious complications, including pyelonephritis, bacteremia, and stone formation, which inflict severe damage to kidney tissue and may block catheterization $(34,35)$. P. mirabilis expresses several putative virulence factors, such as urease, 
immunoglobulin $(\mathrm{Ig}) \mathrm{G}$, and $\mathrm{IgA}$ protease, outer membrane proteins, and fimbriae (36). However, studies of infant UTI caused by $P$. mirabilis have generally been rare. We show here that $P$. mirabilis positive UTI was detected in $15.9 \%$ of isolated specimens of $P$. mirabilis $(10 / 29,34 \%)$ from turbid or sedimented urine from 29 infant cases of $10^{4} \sim 10^{5}$ CFU/ml UTI (data not shown). We tested the ure gene of P. mirabilis ( 7 cases of $10^{4} \sim 10^{5} \mathrm{CFU} / \mathrm{ml}$ counted UTI and 3 cases of $10^{2} \mathrm{CFU} / \mathrm{ml}$ included), which were found by monoplex PCR $(6 / 10,60.0 \%)$ to be positive (data not shown) in infants. The urease production test with urea broth was positive in 7 of 10 cases (70\%) (data not shown).

The results of this study suggest that for infant patients who have suspected UTI and fever, particularly when the urine is turbid, sedimented, or evidences gross hematuria, the clinician should pay close attention to the detection of combined or multiple bacterial and viral infections to determine optimal treatment for the UTI.

\section{REFERENCES}

1) Hsiao AL, Chen L, Baker MD. Incidence and predictors of serious bacterial infections among 57- to 180-day-old infants. Pediatrics 2006;117:1695-701.

2) Chang SL, Shortliffe LD. Pediatric urinary tract infections. Pediatr Clin North Am 2006;53:379-400, vi.

3) Sedberry-Ross S, Pohl HG. Urinary tract infections in children. Curr Urol Rep 2008;9:165-71.

4) Zorc JJ, Kiddoo DA, Shaw KN. Diagnosis and management of pediatric urinary tract infections. Clin Microbiol Rev 2005;18:417-22.

5) Marcus N, Ashkenazi S, Yaari A, Samra Z, Livni G. NonEscherichia coli versus Escherichia coli communityacquired urinary tract infections in children hospitalized in a tertiary center: relative frequency, risk factors, antimicrobial resistance and outcome. Pediatr Infect Dis J 2005;24:581-5.

6) Prajapati BS, Prajapati RB, Patel PS. Advances in management of urinary tract infections. Indian J Pediatr 2008;75:809-14.

7) Johnson JR, Stapleton AE, Russo TA, Scheutz F, Brown JJ, Maslow JN. Characteristics and prevalence within serogroup O4 of a J96-like clonal group of uropathogenic Escherichia coli O4:H5 containing the class I and class III alleles of papG. Infect Immun 1997;65: 2153-9.

8) Akiyama H, Kurosu T, Sakashita C, Inoue T, Mori Si, Ohashi $\mathrm{K}$, et al. Adenovirus is a key pathogen in hemorrhagic cystitis associated with bone marrow transplantation. Clin Infect Dis 2001;32:1325-30.

9) Bedi A, Miller CB, Hanson JL, Goodman S, Ambinder $\mathrm{RF}$, Charache $\mathrm{P}$, et al. Association of $\mathrm{BK}$ virus with failure of prophylaxis against hemorrhagic cystitis following bone marrow transplantation. J Clin Oncol 1995;13:1103-9.

10) Azzi A, Cesaro S, Laszlo D, Zakrzewska K, Ciappi S, De Santis R, et al. Human polyomavirus BK (BKV) load and haemorrhagic cystitis in bone marrow transplantation patients. J Clin Virol 1999;14:79-86.

11) Park HK, Jung YJ, Chae HC, Shin YJ, Woo SY, Park $\mathrm{HS}$, et al. Comparison of Escherichia coli uropathogenic genes ( $k p \mathrm{~s}, u s p$ and ire $A)$ and enteroaggregative genes (aggR and aap) via multiplex polymerase chain reaction from suprapubic urine specimens of young children with fever. Scand J Urol Nephrol 2009;43:51-7.

12) Arisoy M, Aysev D, Ekim M, Ozel D, Köse SK, Ozsoy $\mathrm{ED}$, et al. Detection of virulence factors of Escherichia coli from children by multiplex polymerase chain reaction. Int J Clin Pract 2006;60:170-3.

13) Kanamaru S, Kurazono H, Ishitoya S, Terai A, Habuchi $\mathrm{T}$, Nakano M, et al. Distribution and genetic association of putative uropathogenic virulence factors iroN, iha, kpsMT, ompT and usp in Escherichia coli isolated from urinary tract infections in Japan. J Urol 2003;170:2490 -3 .

14) Russo TA, Carlino UB, Johnson JR. Identification of a new iron-regulated virulence gene, ire $A$, in an extraintestinal pathogenic isolate of Escherichia coli. Infect Immun 2001;69:6209-16.

15) Persson S, Olsen KE, Scheutz F, Krogfelt KA, GernerSmidt P. A method for fast and simple detection of major diarrhoeagenic Escherichia coli in the routine diagnostic laboratory. Clin Microbiol Infect 2007;13: 516-24.

16) Aranda KR, Fabbricotti SH, Fagundes-Neto U, Scaletsky IC. Single multiplex assay to identify simultaneously 
enteropathogenic, enteroaggregative, enterotoxigenic, enteroinvasive and Shiga toxin-producing Escherichia coli strains in Brazilian children. FEMS Microbiol Lett 2007;267:145-50.

17) Park HK, Woo SY, Jung YJ, Lee EO, Cha JE, Park HS, et al. Detection of virulence genes of Staphylococcus aureus and Staphylococcus epidermidis isolated from suprapubic urine from infants with fever. J Bacteriol Virol 2008;38:189-96.

18) Tristan A, Ying L, Bes M, Etienne J, Vandenesch F, Lina G. Use of multiplex PCR to identify Staphylococcus aureus adhesins involved in human hematogenous infections. J Clin Microbiol 2003;41:4465-7.

19) Arciola CR, Campoccia D, Gamberini S, Donati ME, Baldassarri L, Montanaro L. Occurrence of ica genes for slime synthesis in a collection of Staphylococcus epidermidis strains from orthopedic prosthesis infections. Acta Orthop Scand 2003;74:617-21.

20) Hatakeyama N, Suzuki N, Yamamoto M, Kuroiwa Y, Hori T, Mizue N, et al. Detection of BK virus and adenovirus in the urine from children after allogeneic stem cell transplantation. Pediatr Infect Dis J 2006;25: 84-5.

21) $\mathrm{Xu} \mathrm{W}$, Erdman DD. Type-specific identification of human adenovirus 3,7 , and 21 by a multiplex PCR assay. J Med Virol 2001;64:537-42.

22) Trabulsi LR, Keller R, Tardelli Gomes TA. Typical and atypical enteropathogenic Escherichia coli. Emerg Infect Dis 2002;8:508-13.

23) Matar GM, Abdo D, Khneisser I, Youssef M, Zouheiry $\mathrm{H}$, Abdelnour G, et al. The multiplex-PCR-based detection and genotyping of diarrhoeagenic Escherichia coli in diarrhoeal stools. Ann Trop Med Parasitol 2002; 96:317-24.

24) Routh JC, Alt AL, Ashley RA, Kramer SA, Boyce TG. Increasing prevalence and associated risk factors for methicillin resistant Staphylococcus aureus bacteriuria. J Urol 2009;181:1694-8.

25) Decker DB, Karam JA, Wilcox DT. Pediatric hemorrhagic cystitis. J Pediatr Urol 2009;5:254-64.

26) Miyamura K, Takeyama K, Kojima S, Minami S,
Matsuyama K, Morishima Y, et al. Hemorrhagic cystitis associated with urinary excretion of adenovirus type 11 following allogeneic bone marrow transplantation. Bone Marrow Transplant 1989;4:533-5.

27) Hatakeyama N, Suzuki N, Kudoh T, Hori T, Mizue N, Tsutsumi H. Successful cidofovir treatment of adenovirus-associated hemorrhagic cystitis and renal dysfunction after allogenic bone marrow transplant. Pediatr Infect Dis J 2003;22:928-9.

28) Fanourgiakis P, Georgala A, Vekemans M, Triffet A, De Bruyn JM, Duchateau V, et al. Intravesical instillation of cidofovir in the treatment of hemorrhagic cystitis caused by adenovirus type 11 in a bone marrow transplant recipient. Clin Infect Dis 2005;40:199-201.

29) Paduch DA. Viral lower urinary tract infections. Curr Urol Rep 2007;8:324-35.

30) Erdoğan O, Bülbül M, Demircin G, Oner A, Memis L. Acute necrotizing tubulointerstitial nephritis due to systemic adenoviral infection. Pediatr Nephrol 2001;16: 265-8.

31) Allen CW, Alexander SI. Adenovirus associated haematuria. Arch Dis Child 2005;90:305-6.

32) Gardner SD, Field AM, Coleman DV, Hulme B. New human papovavirus (B.K.) isolated from urine after renal transplantation. Lancet 1971;1:1253-7.

33) Gonzalez JL, Balestra S, Schned AR, Gutmann EJ, Tsongalis GJ. Polyomavirus infection of the urinary tract presenting as hemorrhagic cystitis in an immunocompetent five-year-old boy. Diagn Cytopathol 2008; 36:375-8.

34) Rocha SP, Elias WP, Cianciarullo AM, Menezes MA, Nara JM, Piazza RM, et al. Aggregative adherence of uropathogenic Proteus mirabilis to cultured epithelial cells. FEMS Immunol Med Microbiol 2007;51:319-26.

35) Coker C, Poore CA, Li X, Mobley HL. Pathogenesis of Proteus mirabilis urinary tract infection. Microbes Infect 2000;2:1497-505.

36) Rózalski A, Sidorczyk Z, Kotelko K. Potential virulence factors of Proteus bacilli. Microbiol Mol Biol Rev 1997; 61:65-89. 